\title{
(息)
}

Citation:

Pechurina, A (2020) Researching Identities through Material Possessions: The Case of Diasporic Objects. Current Sociology. ISSN 0011-3921 DOI: https://doi.org/10.1177/0011392120927746

Link to Leeds Beckett Repository record:

https://eprints.leedsbeckett.ac.uk/id/eprint/6011/

Document Version:

Article (Accepted Version)

The aim of the Leeds Beckett Repository is to provide open access to our research, as required by funder policies and permitted by publishers and copyright law.

The Leeds Beckett repository holds a wide range of publications, each of which has been checked for copyright and the relevant embargo period has been applied by the Research Services team.

We operate on a standard take-down policy. If you are the author or publisher of an output and you would like it removed from the repository, please contact us and we will investigate on a case-by-case basis.

Each thesis in the repository has been cleared where necessary by the author for third party copyright. If you would like a thesis to be removed from the repository or believe there is an issue with copyright, please contact us on openaccess@leedsbeckett.ac.uk and we will investigate on a case-by-case basis. 


\section{Researching Identities through Material Possessions: The Case of Diasporic Objects}

\section{Abstract}

The article aims to contribute to the growing literature on exploring relationships between objects, homes, and identities in the context of migration. Using examples from a qualitative study of homemaking practices of Russian-speaking communities in the UK, the article discusses how the presence and use of certain objects and foods reflects complex meanings about home and belonging. Specifically, the article deploys the idea of 'diasporic' objects that signify the ambivalent nature of migrants' relationships with their past and present homes simultaneously acting as symbols of connection and detachment. As the objects 'travel' through different homes so too do their meanings, and, through this, 'diasporic' objects accumulate new values and biographies embedded in wider cultural and transnational contexts. Analytically, the concept of diasporic objects is offered as a way to approach the feeling of home as a changing category that is (re)produced through memories and senses, as well as through particular ways of appropriation and personalisation of spaces and places.

\section{Keywords:}

diasporic objects, food, feeling of home, belonging, Russian diaspora 
Author Anna Pechurina, Senior Lecturer in Sociology, Leeds Beckett University

Corresponding author details Dr Anna Pechurina, Leeds Beckett University, CL916 Calverley Building, City Campus, Leeds LS1 3HE. email: a.pechurina@leedsbeckett.ac.uk

\section{Introduction: migrants' homes, objects, and attachments}

Within the many stories of movement one can find many objects. Objects, whether they are real or imagined, lost or forgotten, act as powerful symbols of migrant and diasporic belonging; they 'mediate but also create contexts of movement and (often temporary) settlement' (Basu and Coleman, 2008: 323). The importance of using material objects and possessions to research migrants' lives, attachments, and identities has been firmly established by the growing body of scholarship that explores variations in objects' meanings as well as relationships and affects that evolve around them (Burrell, 2008; Frykman, 2009; Mehta and Belk, 1991; Svasek, 2012; Tolia-Kelly, 2006). Objects are seen as markers of migrants' identity that help to balance and negotiate established attachments to their home country and newly developed connections with the receiving one. (Giorgi and Fasulo, 2013; Rosales, 2010). Such items as souvenirs from home (Demers, 2016; Pechurina, 2011), furniture, items of decor, and food (Dibbits, 2009; Savas, 2014) that find their way into migrants' homes act as important points of reference to migrants' 
biographies, memories and relationships maintained across different countries revealing 'multifaceted quests and attempts to belong'. (Frykman, 2009: 107).

In addition, research that is broadly associated with the so-called 'affective turn' in social theory (Clough et al., 2007) has provided a useful analytical lens for researching material cultures in the context of migration. Some recent studies in this area indicate that certain objects - either left behind or carried through the border - are associated with strong emotional investment (Svasek, 2012); they acquire affective value (Ahmed et al., 2003), or become 'sensitive' (Frykman, 2016). As Baldassar (2008) shows in her study of Italian migrants in Australia, transnational relationships with relatives and loved ones are experienced through emotions - of longing and missing the family - which are manifested through creating situations of 'co-presence' that can involve both tangible and intangible elements.

In the same way as objects, food carries strong emotional connections with one's home country (Abbots, 2016). Food, the ingredients, smells, and the related practices of cooking evoke memories of home (Rabikowska, 2010) as well as act as important connectors to events, journeys and experiences that one undertakes throughout their lives. In this sense, food is an 'emotional "object" (Locher, 2005), that produces a range of feelings that can "reveal" the losses and gains inherent in migrant foodways' (Coakley, 2012: 321). Importantly, the meanings of food are changeable and contextual; in this 
context it is more productive to talk about 'hybridised' meanings of food (Abbots, 2016; Chapman and Beagan, 2013) when meanings are added and mixed to reflect multiple attachments and identities. Thus, food from home is not a static thing that can be preserved in its authenticity, but rather a lived and relational experience that is constantly reconfigured and reinvented within new cultural settings.

Moreover, material objects, food and products of the soil have been the subject of research which has been developed as part of broader theoretical and empirical explorations of the concept of home in the context of international migration (Christou and Janta, 2019, Christou and King, 2010, Rosales, 2009). Home, which is defined by this body of work as a dynamic and multidimensional concept, is seen as an important focal point of migrant and diasporic belonging and identity. By studying how homes are made, in the course of the everyday - i.e. through accumulating or leaving behind objects and belongings, developing multiple attachments, affects and relationships to people, places and spaces, through activities, rituals and interactions, through tastes and atmospheres - researchers offer insights into how identities and cultures are creatively built and reshaped in the course of movement and migration. The focus of research is not on movement from fixed point $\mathrm{A}$ to fixed point $\mathrm{B}$, but on continuous sets of 'meaningful relationships, re-collections and aspirations' (Boccagni, 2017: xxiv), these being established in multiple places over time. By decorating and furnishing 
homes in a particular way, one 'can participate in the (re)making, negotiating and acknowledging of one's place in the world' (Rosales, 2010: 521) or producing their identity narrative (Lawler, 2008).

The connection between the meanings of domestic objects and food and the construction of a feeling of being at home is the main focus of this article which uses empirical data from research on the homes and homemaking practices of Russian migrants in the UK. By considering objects such as home country souvenirs and foods that are associated with national cuisine, the article aims to contribute to the understanding of how materialities, textures and tastes help produce a sense of home and Home(land) that simultaneously refers to the experiences of the past and present. The particular example of souvenirs is used to demonstrate how their stereotypical meanings can be 'peeled off' to reveal new sets of associations related to personal biographies, homes, and belonging: on the one hand, when found in migrants' homes, objects such as matryoshka dolls, khohloma pottery, traditional handicrafts and Soviet paraphernalia tend to be instantly recognised as symbols of cultural and national identity, but, on the other hand, they can also be linked to personal biographies and wider networks of belonging. Along with souvenirs, the article will also discuss how the meanings of 'foods from home' are reinvented to reflect cultural attachments associated with both country of origin and the new cultural settings. The tastes and textures of food produced and consumed within migrant and diasporic settings may call to 
mind childhood memories or recreate the flavours of the Homeland, but they are also new tastes related to the life and homes of the present time.

The conceptual framework of 'diasporic objects' is used as a way to bridge relationships between cultural identity and the meaning of home constructed in the context of movement and migration. According to Svasek (2012) and Vanni (2013) diasporic objects are understood as objects that are detached from their place of origin; through their subsequent use and ownership they are invested with new sets of meanings. These objects have a twofold function: while connecting migrants with their distant homes and cultural heritage they also act as reminders of the sense of detachment from those settings and experiences. In this sense, as a migration experience itself, the meaning of diasporic objects is ambivalent and simultaneously refers to experiences, feelings and attachments that are both familiar and strange and continuously reinvented through the course of everyday life.

The theoretical and methodological framework is clarified below followed by discussion of the domestic objects and foods that can be designated as 'diasporic'. The final section evaluates the presented conceptualising of material cultures and foods in relation to research on migrant and diasporic homemaking more generally.

Theoretical and methodological framework: researching diasporic communities, homes, and objects 
The article attempts to contribute to the understanding of how the meanings and use of particular objects and foods are involved in the process of (re)constructing and (re)inventing the feeling of being at home in the context of a diasporic community. Russian communities in the UK, which this article uses as a case study, are conceptualised in diasporic terms ${ }^{1}$ to tackle the particular type of de-territorialised identity and homeland-orientation that emerged after the collapse of the USSR. The opening of borders has resulted in a change of emigration flows both in size and composition which also has a bearing on how identities are constructed and performed in immigration (for more details see for instance Nikolko and Carment, 2017). Russian migration to the UK reflects these trends particularly well. A dramatic increase in the numbers of arrivals from Russia and former Soviet states has been noted since the early 1990s, changing it from a relatively small community into a diverse migrant body that includes those who arrived as part of different waves of migration (Soviet and post-Soviet), representatives of different generations (e.g. first and second generation of migrants), and Russians and Russianspeakers coming from Russian and countries of the former Soviet bloc or the USSR itself (Byford 2012). The established communities are unique in a sense that while largely sharing common cultural and linguistic backgrounds they are also quite diverse in their experiences of home and migration that relate to both Soviet and post-Soviet cultural forms. This has created a situation where identifications and relationships with homeland (and the 
understanding of where and what the homeland is) are fragmented and ambiguous and where categories and identities such as Soviet, Russian, and post-Soviet co-exist and are discursively and practically performed within the same setting (Byford, 2009a). With regards to the specific case of Russian speakers in the UK, Byford's theoretical framework that puts emphasis on its processual nature is particularly useful as it shifts the focus from seeing it as a distinct community or network to approaching it through 'specific patterns of exchange, of performance and of rhetoric' realised within and through changeable settings and sets of interactions (Byford, 2009a: 56-57). This approach is largely shared in the context of this article which approaches cultural identity as a transformative and changeable category, which is 'constructed across different, often intersecting and antagonistic, discourses, practices and positions' (Hall, 2000: 17).

The empirical data for this paper derives from a wider study that aimed to explore relationships between practices of homemaking and cultural identities among Russian communities in the UK during which 32 homebased interviews were conducted with Russian-speakers from mixed social and generational backgrounds and who resided in the UK over a span of 5-40 years ${ }^{2}$. Building on the body of work which emphasises the connection between materiality of home and cultural identity in immigration, domestic objects that migrants either bring, keep or later acquire were used as a 'way in' to explore wider interconnected practices related to culture building, 
identity construction, sense of belonging and strategies of adaptation and integration .

This article focuses on the group of objects such as national souvenirs and touristy items in order to consider the role of these objects in the process of construction of a sense of home. One of the reasons why these objects were chosen is because they demonstrated interesting variations in the meanings of Russianness and a related feeling of home. Thus, while appearing visibly Russian the objects also revealed a lot more nuanced and complex meanings associated with specific personal events and biographies as well as acted as references to contexts associated with the experience of migration and related practices and senses related to a feeling of home - both past and present. Importantly, it should be noted that accumulating souvenirs is not presented here as a typical characteristic of Russian migrant communities; it is of course, not uncommon to find such items in non-Russian homes too. But if and when these objects appear in Russian homes they can reveal how identities are constructed and (re)presented in the course of migration. In addition, consideration is given to how food and food objects and related practices of their consumption can undergo processes of signification that also produce new sets of meanings and associations that put emphasis on the country of origin and indicate a detachment from it at the same time. By using the examples of foods that are produced in the UK such as Kefir dairy drink 
I will attempt to show how these examples invite reinterpretation of national food in a transnational or diasporic context.

The collaborative or shared aspect of knowledge production should be acknowledged here: the objects were not discovered or noticed by me alone, and even the most visible objects would not reveal their meaning if this was not explained by their owners. During my interviews, home, with its tangible and intangible elements, was both presented and perceived, it appeared and was examined at the same time and this provided an important context for finding shared meanings and understandings. In the empirical analysis that follows, a self-reflexive approach is adopted as a way of writing about objects specifically to emphasise the shared and intertwined nature of knowledgemaking. As I have moved between life stages, times, places and spaces, my own responses transformed too and this further informed my writing (Stanley and Wise, 1990). Hence, the conversations between me and my participants that constituted the base of my research data are still very much on-going, and continue to permeate my analytical and writing strategy. Part of this strategy is itself a dialogue undertaken with myself as I am writing this now and referring to events that happened several years ago. While my focus remains the same, my perceptions and interpretations of meanings alongside my feelings about them have certainly been modified, and I hope that I have been able to reflect this through my writing. 


\section{Example 1: The role of diasporic objects in migrants' homemaking:}

\section{Russian souvenirs and touristy kitsch}

In the Future of Nostalgia, when describing her experience of interviewing ex-Soviet immigrants in the United States, Boym (2001) notes that she was struck by the number of souvenirs, calendars and other Russia-related 'useless objects' kept on display at homes whose inhabitants had by that time lived in the US for at least 10 years and generally could be considered as 'welladjusted' to American life (328). Although some homes looked like stereotypical 'Moscow apartments' left behind ten or more years ago and appeared as some sort of 'personal memory' museums, this did not mean that reconstructing the homes of the past was the sole purpose of those decorating activities. Rather, as Boym points out, the objects and their meanings told stories about life after the border crossing and the experiences of building a new life in a new context. In this context those objects, or 'diasporic souvenirs' as Boym refers to them, appear as 'transitional objects that reflect multiple belonging' (336).

I was able to reflect on this example with my own experience when I bought my first matryoshka after 11 years of living in the UK. Aimlessly browsing through the usual charity shop assortment, I spotted a heavily used, familiar wooden toy and wanted to buy it straight away. I remember thinking in passing, that it was a good moment to get one. As somebody who has been involved in studying migrants' homes for many years I wondered whether 
there were any similarities between Boym's or my own research participants and whether my spontaneous purchase reflected my wish to be connected to my culture or imagined community. Or, could it be that my cultural adjustment to life in the UK meant taking a certain level of distance from Russia which I started to see with something of a 'tourist gaze'? Or, maybe, I was thinking of my UK-born daughter for whom I wanted to see some of the Russian objects that would remind her of her cultural heritage? Regardless of the key motivation behind buying the souvenir, by buying it and then bringing it home I was contributing to its ‘transition’ (Svasek 2012: 3), or, (re)creating its biography that reflected and would become interconnected with my everyday life in the UK. Whether I would put it on display somewhere in the house or use it as a toy or give it as a gift to somebody, the meaning of the Russian doll was reinvented. It has become a souvenir with a personal value as it would always refer to that moment marking the 11th year in my experience of being an immigrant.

While research highlights that, similar to my personal experience, migrants tend to turn to familiar-to-them items such as national souvenirs to counterbalance cultural contexts of their current lives (Mehta and Belk, 1991) on many occasions these items were received by my participants from family and friends either in Russia or in the UK. Further discussions revealed quite widespread practices of gift-giving, when things like souvenirs and folk crafts would be given to those living abroad as a non-serious, playful symbol of 
Russia, presumably to emphasise some level of cultural detachment of the gift receiver from Russia. 'Someone probably gave it to me', was one of the most common answers. Many of those items shared a similar fate: once brought home they would be allocated a space on a shelf and would become almost invisible to their owners for some time. They could be noticed again at the moment of moving house, when a decision needed to be made whether to pack them for the next home or leave them behind. Or, as it happened they would be noticed by me, a researcher looking for signs of Russianness within migrants' homes. These 'breaking points' are important for understanding the significance of some of those items and the reasons for keeping them — it would appear that some are kept and carried not because of their visible Russianness as such, but because of the people who gave them, or because of the moment of purchasing or a particular event in one's biography that they remind the subject of. Maria (28 yo, married $)^{3}$ cherished her samovar set because she would always remember her journey with it from Russia to the UK, when she had to carry a heavy item as hand luggage and explain at the border what it was for. Oleg (48 yo, divorced) kept on display his military helmet ${ }^{4}$ that was given to him by a friend in Russia, which he wore on a flight on a subsequent journey back to the UK under the suspicious gaze of his fellow passengers. Larissa (36 yo, married) admitted that she would always keep her Khokhloma wooden spoons bought on her trip to Amsterdam because her kids liked playing with them. When thinking of such sudden 
moments of visibility, Heidegger's concept of 'worlding' is useful for describing the types of possessions that constitute the invisible background for the everydayness, 'the totality of things" ... "present-at-hand in the world' (Frykman, 2016: 23), and, although this backdrop may not be consciously noticed by the owners ${ }^{5}$, it is still vital for their identity and for making sense of their living experiences. The objects become incorporated into the material worlds of everyday life, so they become inseparable from that spot on the shelf, that house, that street, the view from the window and even the weather, they become a part of the identity of the home.

Research shows that filling houses with familiar objects from the home country helps produce a cozy and homely feel (Boym, 2001; Miller, 2008) qualities that are important in immigration. Home décor and items on display can also indicate the types of relationships the owners have with the receiving culture, and something of their attitudes towards it (Giorgi and Fasulo, 2013, Pechurina, 2015). Moreover, cultural tensions outside the house can be balanced by the choice of items in the house, in which case domestic space appears as a 'safe haven'. On such occasions souvenirs and crafts from home provided a level of familiarity and comfort into the home in a situation when the world outside it feels too different. For instance, Nikolai (36 yo, married) admitted feelings of social isolation from British and Russian circles alike and by keeping 'Russian' things throughout the house he and his family 
created a home that reflected their cultural background as well as marked their difference from others.

Using their home and the objects within it as a way of representing their identity was not uncommon and often stereotypical souvenirs were used as a convenient way of showing connections to culture in a straightforward way. For instance, Maria (28 yo, married), Natalie (40 yo, divorced) and Larissa (36 yo, married) all admitted the straightforward familiarity of matryoshka and that 'it is such a common souvenir and it is a symbol of Russia at the same time' (Natalie) was one of the reasons that attracted them to buy it, so it can be put on display as a symbolic reference to their culture that can be easily recognised by others. However, in relation to this practice it is important to acknowledge that some objects can appear as 'ethnic objects' that aim to signify a particular type of domesticity and class-related taste (see for instance, Olesen, 2010). Some collections of national crafts were indeed carefully pre-selected to fit thought-through 'ethnically-themed' interiors; for example in the case of Maria (28 yo married) who decorated her kitchen in a traditional style, or Olga's (42 yo, married) home featuring traditional souvenirs of antique quality. A more careful examination of these types of objects would certainly lead us to the discussion of class and of related normative aesthetics that are outwith scope of this paper.

To sum up, the point that I am trying to make here is that although souvenirs can be regarded as obvious and stereotypical symbols of Russianness, on 
closer inspection their meaning is not that uncomplicated. Mass-produced artefacts become deeply personal, continuously bringing different fragments of migration stories and biographies helping migrants to make sense of their cultural and personal attachments.

\section{Example 2: Understanding food and foodways as diasporic practice}

From my very first home visit for an interview in 2007, the subject of food came up strongly in my research both as part of the conversations and as part of the actual experience of cooking or eating it together with the participants. Food manifested its presence within homes, through tastes, smells, photographs and pictures on the walls, cooking and eating, through memories, and stories of the past and hopes for the future.

When exploring food and foodways in the context of Russian migrant communities in the UK more specifically (see Pechurina 2015 and 2017), I discovered that migrants' food-related narratives incorporated different elements from both Soviet and post-Soviet cultures and were used as reference points to describe the 'Russian' way of dealing with food. For example, such practices as queuing for food, the Soviet phenomenon of kitchen culture, and ambivalent relationships towards Western food were referred to as cultural characteristics that affected or even defined my participants' attitudes and strategies and behaviour in the UK (Pechurina, 2015: 114-132). When talking to my participants about their practices around the mobility of food, the importance of bringing 'foods from home' was also 
revealed, for instance, certain types of sausages, dairy products, grains and so on were brought even if those foods were accessible in the UK. In relation to this I argued that bringing familiar foods was a way of maintaining the consistency of the migration experience and was used as a strategy for finding one's identity within the context of the receiving culture. The very process of carrying those 'Russian' foods from one country to another, across borders, helped to reformulate its meaning, making it more or less significant or special for the person or community incorporating it within cultural repertoires in the receiving society.

At the same time, while helping to connect people to their home country food also acts as a way of creating attachments in the current place of living. Thus, food practices become 'hybridised' when elements of different foods and ways of cooking get modified, for instance, cooking traditional meals using 'replacement' ingredients, growing foods at home from allotments, incorporating various traditional foods into one's everyday diet, or mixing traditional festive foods together, e.g. during Christmas or New Year celebrations and so on. My argument is that while these practices connect people with the home of the past and help to maintain established cultural attachments, they also produce new sets of meanings related to the everyday experience of migration. It is not always the case that upon their arrival in a new country migrants are fully equipped with cooking skills and a knowledge of traditional recipes; in fact, it is not uncommon that the (re)discovery of 
national food happens some time after living in the receiving country, when the food of home presents itself as one of the defining elements of migrants' identity (Raman, 2011). In the context of post-Soviet diasporic communities, the interest in national food can be also explained by the idea of 'second-hand nostalgia' (Matonyte, 2013: 112), where foods of the (Soviet) past are recreated in a positive way, as part of childhood memories. As a result, some tastes from the past are reproduced or reinvented in a de-contextualised way (Smith, 2006: 201). For instance, participants mentioned cooking traditional Soviet salads for New Year's party as a continuation of family tradition rather than a way of connecting to the USSR.

Another example of hybridised food practice can be the case when some national foods are reproduced in the receiving country both for personal consumption and for sale to wider consumer base as a type of an 'ethnic product'. Russian kefir, is a good example here which was often mentioned during my interviews as one of the typical products that people missed or struggled to find in the UK. Although the drink could be found in the Polish/Eastern European grocery stores some people still missed the 'authentic' taste from home.

For instance, one of my research participants Anya (30 yo, single) who has lived in the UK since 2004 happily told me about her impressions of the online grocery shop that delivers organic food: 'I cannot believe how good their kefir is, I started ordering it by the boxful. It's produced in the UK, but 
it is so good that I even sent a personal message to the company to say how amazing it is!' On the other hand, Dasha's account reflected a different attitude towards food. After describing a long list of Russian foods she could eat right away she added: 'Of course I eat all these here — bread, fish and preserves, but it is still very different. The name of the food is the same, like 'pastry', 'sardines', but the content is very, very different'. In a similar way, Olga and Kostya, a couple in their 30s, told me about the different quality of UK products that are not suitable for Russian cooking: as a result, they made their own kefir using so-called 'kefir grains' and their own kombucha6. 'Products are different here and in the beginning it wasn't possible to cook anything. There are at least ten different versions of the same product but only one will be suitable for what you want to cook. So, for instance, kefir we make ourselves'.

In recent years, however, kefir has become more visible within the British context and can now be found not only in independent ethnic grocery shops, but also in up-market supermarket chains and grocery stores. By looking at the way it is positioned within the multi-ethnic food context of the UK it is possible to observe how some foods associated with particular cultures can acquire new meanings and biographies. When introducing their product some UK-based producers of kefir, while describing the product as produced in the $\mathrm{UK}$, also retain the reference to their ethnic origins, however vague and distant, as if to affirm its 'authentic' background'. Thus these products 
presented as having 'authentic' background and they are also linked to the UK, they are offered to a wider range of audience including those who may 'rediscover' the familiar taste as well as those to whom it will appear as completely new. In other words, the products represent a combination of old and new, familiar and unknown.

On an individual level, when throwing products into the supermarket basket it is not just kefir, but also кефир that I will be buying and drinking. Or, while ordering kombucha sitting in a UK cafe with my American based friend we will share smiles reminiscing on the times when our parents used to grow kombucha of the past or 'чайныци гриб' in big three-litre glass jars. Regardless of its packaging and place of production, the taste would evoke very familiar associations that once again remind us of the place we grew up in, as well as the (long) distance from it. The product's meanings are mixed and so are the feelings that it evokes, and the question of whether it brings home closer or makes it even more distant still remains open.

It is important to note that the presented examples are, of course, specific to the UK context where kefir or kombucha are relatively new products not previously distributed through supermarket chains, unlike in some other European countries. It is also important to acknowledge some issues beyond the scope of the presented discussion, but which certainly contribute to how diasporic foodways are produced and performed, including the political and class dimensions of food, the related constructed notions of some food as 
being more nourishing and healthy, as well as different levels of accessibility of products for different groups of migrants.

\section{Conclusion: Diasporic objects as a way of approaching homemaking in} migration.

In this paper I attempted to highlight how the meanings of domestic objects and food can be used as a way of exploring the production of identities and sense of belonging in immigration. By deploying the idea of diasporic objects I aim to contribute to literature that considers such objects as powerful referents to 'emotional geographies of migration' (Vanni, 2013: 151), that are embedded into the complex processes of reproduction of domestic space both as homely and 'unhomely'. In other words, diasporic objects mark and symbolise experiences and feelings of having been here and there, of being detached and present at the same time. Furthermore, my take on diasporic objects aims at emphasising that the production and reproduction of their meanings is also the product of particular experiences and paths of migration; in other words, they 'make sense' because of and within particular contexts, settings, or communities (Savas 2014, Svasek 2012). In this sense, souvenirs that can be found in Russian homes mark the migration experiences of this particular migrant group and the ways in which relationships and attachments are constructed within this group. By using my own and my participants examples I also aimed to highlight that objects do not appear in homes in a straightforward way, i.e. the circulation and mobilities of domestic items is 
a non-linear process that involves a variety of practices and is linked to a range of emotions (Baldassar, 2008). The objects can be bought spontaneously or intentionally, received as gifts, or passed as inheritance, they can act as reminders of people and places, symbols of nostalgia, or exotic elements of decor. Importantly, the examples offered do not constitute a final list of diasporic objects, nor are they aimed at suggesting that acquiring Russian souvenirs or eating Russian food is a specific characteristic of Russian migrants' homes. But behind their obviously Russian look they reveal a complex, not-so-obvious way of producing Russianness - through signifying attachments, creating meanings, and preserving memories.

The example of food offered some additional thoughts on how the production of its meanings can be discussed in diasporic terms. It can be argued that some national food products acquired diasporic qualities: they are detached from their original context but also connected to it through its reinvented 'biography'. Although they are not presented as specifically Russian foods in the market they can be recognised as such by members of diaspora. When consumed in the receiving country they acquire new sets of meanings and associations that reflect the reinvented qualities of these foods, including its taste, textures and even branding Kefir vs Keфup). Importantly, food related practices should not be considered in isolation from wider contexts and trends that have an effect on availability, popularity and the level of promotion of certain 'ethnic' foods on the market. 
Finally, the suggested way of thinking about objects as diasporic aimed to emphasise the dynamic and changeable nature of home and homemaking. By exploring how the meanings of objects 'travel' alongside those objects and then get continuously 'reinvented' I aimed to offer some insights into how a sense of home and belonging emerge as both cultural and deeply personal experiences.

\section{Acknowledgements}

I would like to thank Carol Smart for inspiring conversations at the time of writing of this article, Ay Salem, Conrad Russell, and Elena Minina for their collegial support, the reviewers for their feedback, and the editors for their very helpful comments.

\section{Notes}

1. Traditionally applied to the Jewish, Greek, and Armenian experience of dispersion and exile from their historic homeland ('classical Diaspora' as coined by Cohen (1997)) the term Diaspora has been largely expanded in recent years to include the broader range of experiences and contexts referred to as 'a larger semantic domain that includes words, like immigrant, expatriate, refugee, guest-worker, exile community, overseas community, ethnic community' (Tololyan, 1991: 4-5). In the context of this article I deploy the concept of diasporic identity that relies on its wider and more flexible definition that puts emphasis on the type of liminal subjectivity and consciousness that emerges within de-territorialised communities in relation 
to their self-identification and sense of belonging. Thus, diasporas are understood here as communities characterised by some level of 'sociocultural or political cohesion in the countries in which they now live' (Story and Walker, 2015: 136) and which maintain a 'sustained connection with a distant place' (Story and Walker, 2016: 136) - an imagined or real territorial homeland.

2. Participants ages ranged between 29 and 70 at the time of interview. The majority of the interviews took place in northwest England in 20072008; a few were conducted in other areas including Scotland, Wales, and the South of England, additional interviews were conducted in 2012 and in 2018 in London and Leeds. Eight participants had lived in other countries before coming to the UK, including Canada, Germany, Holland, UAE, Singapore, and Israel. All Russians interviewed were born during the Soviet era. Most were born in Russian cities; four participants were born in Belarus, Moldova, Ukraine, and Kazakhstan, and two were born in Bulgaria and France.

3. All participants' names have been changed.

4. The item was treated as a souvenir by the owner. Somewhat similar treatment of military accessories by Russian migrants was noticed by Byford when one of his participants kept a Soviet military cap on her fireplace to symbolically mark her country of birth (but not her connection to Soviet ideology) (Byford, 2009b). 
5. This 'invisibility' of things that looked so visibly Russian was quite an interesting feature that once again pointed to differences of how dwellings could be seen and perceived by visitors and inhabitants. Some participants admitted that items were so familiar and did not stand out for them, but for others the practice of not noticing things was more intentional - they felt that they had to keep the gifts not because they liked them but because of the feeling of duty to those who gave them - such as relatives or close friends (see Pechurina 2015: 42-43).

6. 'Kombucha' or 'tea mushroom', as it is also referred to in Russian, is another fermented drink that was commonly home-made in Russia and some people continue doing this in the UK too.

7. See for instance, Bio-tiful Dairy: http://biotifuldairy.com or Nourish's story: http://www.nourishkefir.co.uk/about/.

\section{References}

Abbots EJ (2016) Approaches to Food and Migration: Rootedness, Belonging and Exchange. In: Klein $\mathrm{J}$ and Watson $\mathrm{J}$ (eds) Handbook of Food and Anthropology. London: Bloomsbury.

Ahmed S et al. (eds) (2003) Uprootings/regroundings: Questions of Home and Migration. Oxford and New York: Berg.

Baldassar L (2008) Missing kin and longing to be together: Emotions and the construction of co-presence in transnational relationships. Journal of Intercultural Studies 29(3): 247-266. 
Basu P, Coleman S (2008) Introduction. Migrants worlds, material cultures. Mobilities 3 (3): 313-330.

Boccagni P (2017) Migration and the Search for Home. Mapping Domestic Space in Migrants' Everyday Lives. New York: Palgrave Macmillan.

Burrell K (2008) Materialising the border: Spaces of mobility and material culture in migration from post-socialist Poland. Mobilities 3(3): 353-373.

Byford A (2012) The Russian diaspora in international relations: 'Compatriots' in Britain. Europe Asia Studies 64(4): 715-735.

Byford A (2009a) 'The Last Soviet Generation' in Britain. In: Fernandez J (ed) Diasporas: Critical and Interdisciplinary Perspectives. Inter-Disciplinary Press.

Byford A (2009b) 'Poslednee sovetskoe pokolenie' v Velikobritanii. Neprikosnovennyi Zapas 64: 96-116.

Boym S (2001) The Future of Nostalgia. New York: Basic Books.

Chapman G and Beagan BL (2013) Food practices and transnational identities Food, Culture \& Society 16(3): 367-386.

Christou A and Janta H (2019) The significance of things: Objects, emotions and cultural production in migrant women's return visits home. The Sociological Review 67(3): 654-671.

Christou A and King R (2010) Imagining 'home': Diasporic landscapes of the Greek second generation. Geoforum (41): 638-646.

Cohen R (1997) Global Diasporas: An Introduction. London: UCL Press. 
Clough PT, Halley JO (eds) (2007) The Affective Turn: Theorizing the Social. Durham: Duke University Press.

Coakley L (2012) Polish encounters with the Irish foodscape: An examination of the losses and gains of migrant foodways. Food and Foodways: Explorations in the History and Culture of Human Nourishment 20 (3-4): $307-325$.

Demers H (2016) Dutch immigrant identity as reflected in home artifacts. Canadian Journal of Netherlandic Studies. 37(1): 119-131.

Dibbits H (2009) Furnishing the salon: symbolic ethnicity and performative practices in Moroccan-Dutch domestic interiors. International Journal of Consumer Studies. 33: 550-557.

Frykman J and Frykman MP (eds) (2016) Sensitive Objects: Affect and Material Culture. Lund: Nordic Academic Press.

Frykman MP (2009) Material aspects of transnational social fields: An introduction. Two Homelands 29: 105-114.

Giogi S and Fasulo A (2013) Transformative homes: squatting and furnishing as sociocultural projects. Home Cultures 10(2): 111-133.

Hall S (2000) Who Needs 'Identity'? In: Du Gay P, Evans J and Redman P (eds) Identity. A Reader, London: Sage Publications.

Lawler S (2008) Identity: Sociological Perspectives. London: Polity. 
Locher JL et al. (2005) Comfort foods: An exploratory journey into the social and emotional significance of food. Food and Foodways: Explorations in the History and Culture of Human Nourishment 13(4): 273-297.

Matonyte I (2013) Political reconsideration of the Soviet past: Attitudes and actions of the Lithuanian elites. Baltic Region 2013(3): 86-97.

Mehta R and Belk RW (1991) Artifacts, identity, and transition: favourite possessions of Indians and Indian immigrants to the United States. Journal of Consumer Research 17(4): 398-411.

Miller D (2008) Migration, material culture and tragedy: Four moments in Caribbean migration. Mobilities 3(3): 397-413.

Nikolko M and Carment D (eds) (2017) Post-Soviet Migration and Diasporas: From Global Perspectives to Everyday Practices. Oxford: Palgrave Macmillan.

Olesen BB (2010) Ethnic objects in domestic interiors: Space, atmosphere and the making of home. Home Cultures 7(1): 25-41.

Pechurina A (2017) National Food, Belonging, and Identity among Russianspeaking Migrants in the UK. In: Polese A, Morris J, Pawłusz E and Seliverstova O (eds) From Identity and Nation Building in Everyday PostSocialist Life. New York: Routledge.

Pechurina A (2015) Material Cultures, Migrations, and Identities: What the Eye Cannot See. London: Palgrave Macmillan. 
Pechurina A (2011) Russian dolls, icons, and Pushkin: Practicing cultural identity through material possessions in immigration. Laboratorium: Russian Review of Social Research 3(3): 97-117.

Rabikowska M (2010) The ritualisation of food, home and national identity among Polish migrants in London. Social Identities 16 (3): 377-398.

Raman P (2011) 'Me in place, and the place in me'. Food, Culture \& Society 14(2): 165-180.

Rosales MV (2010) The domestic work of consumption: materiality, migration and home-making. Etnográfica [Online] 14 (3) (Accessed 25 April 2019).

Rosales MV (2009) Objects, scents and tastes from a distant home: Goan life experiences in Africa. Two Homelands (26): 153-166.

Savas O (2014) Taste diaspora: the aesthetic and material practice of belonging. Journal of Material Culture 19(2): 185-208.

Silva K (2009) Oh, give me a home: diasporic longings of home and belonging. Social Identities 15(5) $693-706$.

Smith L (2006) Uses of Heritage. London and New York: Routedge. Stanley L and Wise S (1990) Method, methodology and epistemology in feminist research processes. In: Stanley L (ed) Feminist Praxis: Research Theory and Epistemology in Sociology. London: Routledge.

Story J and Walker I (2016) The impact of diasporas: Markers of identity. Ethnic and Racial Studies 39(2): 135-141. 
Svašek M (2012) Moving Subjects, Moving Objects: Transnationalism, Cultural Production and Emotions. New York, NY: Berghahn Books. Tolia-Kelly DP (2006) Mobility/Stability: British Asian cultures of 'landscape and Englishness'. Environment and Planning A 38 (2): 341-358. Tölölyan K (1991) The nation-state and its others: In lieu of a preface. Diaspora 1: 1-7.

Vanni I (2013) Oggetti spaesati, unhomely belongings: Objects, migrations, and cultural apocalypses. Cultural Studies Review 19 (2): 174-195.

Walsh K (2006) British expatriate belongings: mobile homes and transnational homing. Home Cultures 3 (2): 123-44.

Dibbits H (2009) Furnishing the salon: symbolic ethnicity and performative practices in Moroccan-Dutch domestic interiors. International Journal of Consumer Studies. 33: 550-557.

Frykman J and Frykman MP (eds) (2016) Sensitive Objects: Affect and Material Culture. Lund: Nordic Academic Press. 